\title{
Affective War: wounded bodies as political technologies.
}

Leila Dawney, University of Exeter

\section{Introduction}

Bodily injury, according to Elaine Scarry's The Body in Pain, is fundamental to the structure and logic of war. Scarry's meditation on the relationship between language and world, between matter and text, argues that the political work of war takes place most forcefully through wounding and killing. War differentiates itself from any other contest (and is always more than a contest) through its unmaking of the material world: the unmaking of buildings, cities, and crucially bodies.

This paper brings Scarry's concept of substantiation to bear on public stagings of wounded bodies in the UK during and after recent wars. Substantiation, in Scarry's work, refers to the way in which the matter of wounded, maimed and dead bodies works to enflesh ideas. The damaged or altered body functions in war as a vehicle for substantiation: the making material of immaterial beliefs and values. The concept of substantiation thus holds that the material altering of matter is necessary to the political work of war, since it brings into the world the ideas over which war is fought. In other words, wounding inscribes power relations in and through bodies, and makes ideas (for example the idea of 'the nation', or 'the people') visible and palpable to publics. The dead and maimed bodies produced in warfare thus make political claims solid and in doing so materialise language and ideas.

Scarry's argument is based on two premises: first, that wounded and dead bodies have affective power: they affect other bodies. A corollary of this is that publics comprise bodies that can be affected by the wounding (and by referral the pain of) others. The second premise is that the wound is in itself indeterminate, and can therefore be "tied" to particular ideas. Wounded bodies are 
situated and contingent; they can be encountered by different subjects in different ways and in the context of being anchored to different ideas. However, neither of these assumptions is discussed at length in her text, nor the specific processes through which substantiation occurs.

If we take Scarry's assertion that wounding is central to war insofar as it enfleshes ideas through its power to affect publics, we can assume that much of the work of war takes place outside and after the theatres of warfighting. This work involves a process of attaching broken bodies to particular sets of ideas, and staging encounters between these bodies and publics. This requires that such political technologies are rooted in events and locations often away from the battlefield, incorporating the "other spaces" of war, such as what we might consider the "home front" - spaces of civilian life - firmly within its machine (Grondin, 2011). Wounded bodies are mobilised as affective technologies in their encounters with publics in the service of war, to secure and substantiate ideas such as democracy, freedom or the State. Scarry's concept of substantiation, with its focus on the materiality, vulnerability and affective capacities of bodies, provides a useful contribution to understanding the political-affective work that bodies in war do. Rather than seeing these affective technologies as an adjunct to war, then, substantiation places the wounded body at the centre of the political work that war does, and considers the matter of bodies, and their affective capacities, as crucial political technologies.

Building on Scarry, this paper argues that the force of the wound is called upon in a mediation of public affect that draws publics into the affective architectures of war-as-politics, and ties the bodies of publics into relation with the bodies of wounded military personnel. Here, I addresses the lacunae caused by Scarry's abstraction through what I refer to as the "politics of substantiation". While the concept of substantiation spotlights the relationship between wounded bodies and publics in the service of war, and enables a material understanding of the political work of war, the politics of substantiation supplements this with an analysis of the work that these bodies do as political 
technologies, and of the political processes of substantiation. These are the mechanisms through which wounded bodies are rendered visible and through which their affective capacities to compel and grip are mediated. The politics of substantiation refers to the specific work that is done to make these bodies visible and attach particular bodies to particular ideas.

I engage this concept with reference to two examples of the ways in which wounded bodies have been made available to publics in the UK during the war in Afghanistan between 2010-2015: the BBC screening of the Invictus Games in 2014 and the everyday interfaces between publics and the charity Help for Heroes. These examples serve firstly to test the usefulness of the concept for understanding the role of wounding in the manufacture of public consent, and secondly to pay close attention to the process of substantiation itself. There is critical work to be done, after Scarry, in addressing the specific ways in which the matter of war - in the form of wounded bodies - is secured to particular ideas. In the UK, wounded bodies brought to public visibility during the Afghanistan war were largely those of returned British Armed Forces'. Contemporary forms of warfighting and battle equipment mean that British military personnel are more likely to be injured than to die in theatres of war, and encounters with wounded service personnel are one means through which civilian societies in the West witness the violence of war. These bodies are encountered by publics through institutions, screen events, live events and everyday objects. The examples discussed push further at Scarry's concept by addressing specific bodies, in specific situations, subject to specific political stagings of visibility. The paper does not address the visibilities (and invisibilities) of other bodies damaged during these wars, such as civilians and "enemy" soldiers. While this would have provided some important comparative points, the aim here is to focus on the politics of substantiation as it takes place through one particular set of political logics, and it is for this reason that analysis is limited to these cases. 
Since the publication of Scarry's work, a considerable literature engaging with Deleuzian concepts of affect has emerged, constituting the "affective turn" (e.g. Gregg and Seigworth, 2010; Clough and Halley, 2007; Massumi, 2002; Anderson, 2014). In this journal, a special issue on affect has foregrounded the utility of this concept for body studies, stating that "the affective turn specifically encourages engagements with subjects that foreground the question of what do we mean when we invoke, examine and enact the body in body studies". (Blackman and Venn, 2010: 8). This conceptual framework focuses on bodies not just in terms of how they are represented, and how their meaning is constructed, but in terms of what they do: the effects that they have on the world. It operates a processual ontology where bodies, as socio-material entities, are always on the move; always enacting new relations in their encounters with other bodies. In this way, it offers a break from representational or discursive modes of analysis that remain in the domain of hermeneutics. In this paper, the wounded body is understood as a material-affective entity, moving focus away from its representations alone towards how the moment of encounter between wounded bodies and publics is incorporated into political regimes and produces forms of life. The concept of substantiation provides an important contribution to scholarship on affect and war, both through its recognition of the affective power of the broken body and through the excess that this can generate, in terms of affective relations that exceed attempts to control them. This focus on the politics of encounter with bodily wounding contributes to an understanding of how, in Judith Butler's terms, publics are conscripted into wars, and can further elucidate the processes through which the mattering of substantiation occurs (Butler, 2009). The concept of substantiation is here supplemented by an analysis of the precise work that these bodies do as political technologies that incorporate publics into the affective architecture of war. These political technologies are rooted in events and locations; in the everyday and the "other spaces" of war. 


\section{Affective technologies of war}

During the Afghanistan war, the public visibility of wounded British military personnel proliferated in the UK and became, perhaps counterintuitively, one of the main strategies for maintaining public support for the military. Recent scholarship has brought this representation of bodies and wounding to critical attention, broadly focusing on their representational and discursive aspects, for example in History (Koven, 1994), in Media Studies (Gavriely-Nuri and Balas, 2010), and in Military Studies (Cooper and Hurcombe, 2008; Woodward et al., 2009). In Disability Studies, too, the phenomenon of wounded and disabled veterans' games has been addressed with reference to the "supercrip" critique (Howe, 2011; Batts and Andrews, 2011). Despite this interest, much of this scholarship remains in the realm of discourse and meaning, and relatively little attention has been paid to the affective power of such images of wounding, and the work that they do in their encounters with the bodies of publics.

There are a number of notable exceptions, however, that discuss attempts to limit and mitigate the affective power of wounded bodies. One such exception is the work of communications scholar Paul Achter, who argues that the wounded military body is potentially unruly and disruptive: it speaks to the violence of war and can be incorporated into conflicting political narrativisations of this violence. The "unruliness" of wounded military bodies thus necessitates their incorporation in complex aesthetic and disciplinary regimes to ameliorate their disruptive capacity, and their ability to expose the vulnerability of the nation and the "cost" of war (Achter, 2010). The soldier, as witness to war, and his or her wounded body as testimony to that witnessing, constitutes a potentially dangerous presence (Achter 2010; Dawney 2013b). Achter's concern is with the disciplining of these bodies, as metonymic signs for the nation itself, in order to translate their injury into narratives of power, virility and triumph over adversity: "cultural practices take purchase on, pull rhetorically, or otherwise "claw back" images of veterans in ways that flatten their injuries and prevent them from disrupting the inertia that has made war seem permissible and worthy" (Achter, 2010: 48). What is 
clear from Achter's work is a recognition of both the instability and the power of the wounded body, and the means through which its excess is reined in and controlled. Similarly, John Jervis' discussion of the press image of a charred body of an Iraqi soldier after the massacre at Mutlah Gap in the first Iraq war refers to the indeterminacy of the response to violence: "horror, anger, pity are all possible"(Jervis, 2015:198). Yet what is undeniable about the embodied encounter with that image is the visceral: its horror cannot help but elicit a response in most, if not all, of those who encounter it, and this encounter with a body's destruction, despite its openness to alternative meanings, operates prior to and alongside the mode of relating to the politics of the image that follow. The visceral, affective force of the encounter, I argue, is what Scarry means when she points to the specificity of the opened body as the site where war does its work.

The affective politics of opened bodies is also discussed by Jennifer Fluri, who focuses on the gendered and racialised biopolitics of the representational politics of war, discussing how bodies and spaces are incorporated into imagined geographies of the nation through technologies of securitisation (Fluri, 2014). Referring to the visibility of medical technologies such as prosthetics in the staging of events such as the US Warrior Games and a photoshoot of war veterans with Miss America, she suggests that such spectacular prosthetics "distract 'us' away from the devastation of military violence and toward the technological process of corporeal reconstruction" (Fluri, 2104: 805). As she makes clear, these technologies are unavailable to others who are injured, such as civilians who remain in spaces of conflict, and whose injuries are less available to the western spectator. This is echoed in other work on the absence of some bodies in war: John Taylor, in the context of the first Gulf War, has discussed the emergence of a "war without bodies" (Taylor, 1998) where the visibility of atrocity is concealed in favour of the spectacle of firepower and visibilities of dead and maimed victims of war are carefully controlled by western media. The maimed body is shielded from view and its disruptive potential ameliorated by omission. These writers all demonstratethat the display of bodies to publics is carefully controlled. In this way, they offer a testament to the affective power of the encounter that underpins Scarry's argument, and open up 
an approach to understanding the political work that these encounters do. The concept of substantiation, as I will outline below, when brought to bear on these critical literatures, can shed further light on the affective grip that the wound offers, and in doing so, its excess and force.

To understand power as operating in and through affective life enables us to think specifically about the ways in which institutions, representations, events and circulations of images produce affective atmospheres, regimes of affective mediation, and the capacity to affect and be affected. The work of geographer Ben Anderson, in particular, operates a Foucauldian take on affect as political technology, paying attention to its mediation - to the techniques and technologies that produce and work through affect (Anderson, 2014: 8, see also Anderson, 2011; 2010). Addressing power in this way enables us to think about how we are conscripted into these processes through our own bodies' incorporation in aesthetic and affective regimes (Dawney, 2013a). Political formations, such as nationalism or militarism, are experienced as feeling: they are lived, known and felt through and between bodies (Closs-Stephens, 2013). Politics come to matter in the practices and technologies through which affective forms of life take place, and they are given force and substance through the intensities produced in bodies. Wounded bodies matter precisely because of the affective force that they garner - their ability to substantiate ideas is based on their ability to affect and intensify.

There is a growing scholarship on affect in war that responds to these conceptual demands (Colman, 2009; McSorley, 2012; 2014; Masco, 2013; 2014; Anderson, 2010). This scholarship pays attention to the extremes of embodied sensation and death produced through war, to the love and loss that are activated through encountering injuring and killing and to the affective circuits that resonate around populations. Anderson argues that morale, in a state of total war, becomes a means of constituting a target population and an instrument or apparatus for the production of affective life (Anderson, 2014). Similarly, anthropologist Joseph Masco considers how affect operates as a political technology, arguing that during the Cold War and after, apparatuses for the management and 
mediation of public affect, particularly through terror and threat, was one of the primary processes through which the US maintained its planetary "Theater of Operations" (Masco, 2014).

The mobilising of affective technologies in war is also discussed by media scholar Felicity Colman. Colman addresses the role of screen militarism, particularly through emerging media forms such as the military trophy video, arguing that these forms operate affectively through their intense visuality to produce communities as affective bodies and to direct them towards specific places and activities: “activities of militarism direct and orient a community's perceptual consciousness, thereby altering the sense of that community", operating as "modal vectors in our figuring of the behavioural tendencies of communities" (Colman, 2009: 143, 150). Thus, the body's engagement with screen images has the orientative power to impact and change the community - to imagine and alter the world.

Referring specifically to the framing of images of war, Judith Butler describes the apparatus of affective war as comprising cameras, screens and images. Framing, as a particular set of visual and media techniques, refers to the process through which sensate regimes produce ways of apprehending and knowing the world. It produces embodied subjects at the same time as it produces representations of the world. It is part of the materiality of war and the efficacy of its violence. These processes through which visual and discursive regimes frame wounding and its subjects and objects form a material-discursive regime of intensification in the production of grievable and ungrievable lives. In Frames of War, Butler discusses how these processes conscript the public. War works on and through public sensibilities and affects, and as such requires a level of consent which operates as a form of conscription. This conscription works on and through bodies at the level of affect and sensation such that "every war is a war upon the senses" (Butler 2009:xvi).

These scholars address the means through which publics are incorporated in regimes of war (both hot and cold) through architectures of affect. They place the bodies of publics at centre stage, and the affective capacities of publics are necessary for the workings of these architectures of power. As 
such, they focus on the affective technologies of war: the generation of morale and dread in Anderson and fear in Masco, and in the conscription of publics into regimes of liveability and grievability in Butler. They point to the specificities and situatedness of these technologies in the making of worlds, and to the matter of affective war as taking place through relations between bodies and technologies, and most of all to the incorporation of publics in the affective architectures of war. The argument that proceeds draws on and synthesises these thinkers through Scarry's concern with the affective power of the wounded body and its role in the political work of war. Scarry supplements the work of these thinkers through her evoking of the affective excess generated by the wound: her concept of substantiation points to this excess as a central affective technology and armament. However, what she does not discuss, and where these writers move the debate forward, are the specific processes through which bodies and ideas become attached, where the anchoring of the broken body's excess takes place.

\section{The politics of substantiation}

In The Body in Pain, Scarry attempts to "understand the structural logic of an event in which alterations in human tissue can come to be the freedom or ideological autonomy or moral legitimacy of a country" (Scarry, 1985: 81). Contrary to the language used to describe injury in warfighting, Scarry argues that injuring is neither a byproduct nor marginal outcome of war, but rather central to its logic. The inscription of power relations onto bodies through wounding and killing are seen to function both during and after wartime to make the idea of the nation visible and material: the word made flesh. In her discussion of the relationship between body and world, Scarry illustrates how the nation is inscribed on and through bodies in both peacetime and war through practices, habits and embodied modifications that give substance to geopolitical ideas. Bodies are, in this way, necessary to the performance of nation "ii: "the nation may ordinarily be registered in his limbs in a particular kind of handshake or salutation performed for a few seconds each day, or absorbed into his legs and 
back in a regional dance performed several days each year; but the same arms and legs lent out to the state for seconds or minutes and then reclaimed may in war be permanently loaned in injured and amputated limbs" (Scarry 1985:111). The bodies of publics and the bodies of military personnel are imbricated in affective circuits that contribute to the formation of a body politic.

In war, Scarry argues, ideologies, beliefs, thoughts and ideas become "substantiated" through their attachment to wounded and open bodies: "the incontestable reality of the body - the body in pain, the body maimed, the body dead and hard to dispose of - is separated from its source and conferred on an ideology or issue or instance of political authority" (Scarry 1985:62). We can thus infer that injury, and injured bodies place a demand on their witness to pay attention, be affected andfeel moved. This demand takes place through encounters: between broken bodies and the bodies of publics, and gives weight to the ideologies to which they become attached. iii The affective power of such bodies, as they make themselves known and felt through the bodies of others, provides the force and grip for an undoing and a remaking of ideologies, beliefs and political identities. The injured body becomes a site through which political authority travels, and where authoritative relations reside and through which power operates ${ }^{\text {iv. }}$ dead and maimed bodies make solid political claims and in doing so materialise language and ideas. The interiors of bodies are, for Scarry, the "precious ore of confirmation... the mother lode that will eventually be reconnected to the winning issue, to which it will lend its radical substance, its compelling, heartsickening reality" (Scarry 1985:137).

If, as Scarry has argued so eloquently, wounding, and the forms of affective attachment and power that the wounded body produces, are fundamental to the logic of war, then this works in part through producing ways of making wounding visible. Further, as the injured body does not have a necessary relation to any one set of ideas and beliefs, work needs to be done in order to limit or fix that substantiation of ideas and beliefs through bodies. Moving forward with these arguments, I suggest that the idea of substantiation, the movement from idea to matter as a means of world- 
making, operates affectively, and the politics of substantiation are enacted in and through bodies encountering and affecting each other. Scarry's position is material-discursive: she highlights the oscillation between the registers of affect and subjectivity and the making political of the encounter. As such, substantiation is a process: a material movement between bodies.

Scarry's discussion of substantiation contributes to scholarship on war and affect in two ways. Firstly, it makes a clear conceptual argument for considering the force of the wounded body: its "heartsickening reality". Her materialist reading of the body in war is based on the premise that the force of the wound has a unique and specific power to make material abstract ideas. It logically follows from this that the special status of the wounded body, as carrier of memory and materialisation of the world of ideas, works through the fact that the bodies who encounter these also have the potential for that same vulnerability: to feel pain and be broken. The second point that Scarry implies, but does not make explicit, is that there is work to be done in tying ideas to matter. In Scarry's analysis, bodies are rendered equivalent: she does not consider how different bodies might have different affective force when opened, nor how some lives are rendered worth living and some disposable. Her bodies are neither sexed nor racialised. The broken bodies in Scarry's writing are sentient flesh, yet what is not addressed is the specific movement of affect that occurs when the visible inscription of pained experience on these specific bodies register with publics and interact with political subjectivities and imaginaries. Broken bodies affect us because we have a capacity to feel pain and to imagine the pain of others, but only if we feel that their pain matters. Scarry's discussion of substantiation in war does not deal with the historical mediation of the body, and how this takes place through the framing regimes of war (Butler, 2009; Butler, 2004).

The force of the eruption of the broken body in the moment of encounter operates in excess to meaning, and it is precisely its excess that makes it so powerful in its work of substantiation, but also so volatile. The intensity of pain referred to by the broken body constitutes the broken body's demand. Yet, as Butler makes clear in her discussion of grievable and ungrievable bodies, this 
demand is channelled in particular ways, through processes and practices of visibility. It is this that I refer to as the "politics of substantiation". A critical politics of substantiation thus raises the question of the processes through which this demand becomes a technology of authorisation and of legitimation, of how affects are moved, augmented, intensified or deadened in the making of political life, and of the conditions of possibility for particular regimes of visibility to work towards political ends. It is here then, that we can develop Scarry's ideas through an investigation into the the specific instances through which broken bodies are made visible and palpable and the political work that this does. Both Butler and Fluri show how specific bodies are differently incorporated into regimes of affect for political ends. Similarly, Achter's work on unruly bodies points to the need to shore up such images, to ameliorate their affects. If, as Scarry suggests, the wound operates as a powerful but volatile excess, then what these thinkers show is the means through which political technologies control that excess for political ends. Effectively, this points to the openness and potential reversibility of the wound. It has power to affect, and this power may be drawn upon by different actors with different political motives ${ }^{\vee}$.

The next section works through two examples of the making-visible of wounded bodies in the UK in recent wars in Iraq and Afghanistan, paying attention to processes of tying bodies to ideas, and mediating the affective force of substantiation. These examples show that the process of substantiation is not self-evident, as Scarry suggests ${ }^{\text {vi }}$, but requires regimes of staging and making visible in attaching ideas to bodies. Rather than being tied to the "winning ideas", which, in Scarry's work is based on a view of war in terms of a Clausewitzian duel (see McSorley, this volume), war is an ongoing process of statecraft and politics, where the wounded body of the soldier provides a forceful ground: an excess to representation which makes solid the claims of the state. The state is the object in whose names these bodies have been maimed, and it is also the entity which closes the wound, shoring up its leaky and disruptive charge. These examples highlight the role of injuring in the ongoing process of materialising ideas, and the wound as a central affective technology in the garnering of public support for military personnel and interventions. 


\section{Bodies as affective technologies}

Changes to global geopolitics and warfare pose particular problems for governments and military organisations whose legitimacy and authority have historically been based on the unquestioned authority of the state and line of command. Questions of military recruitment without conscription, and of public consent to military activity, led to the commissioning of a UK Government report entitled "National Recognition of our Armed Forces" (Davies et al., 2008). Identifying the importance of public support, the report argued for a reappraisal by the Armed Forces of the priority given to public outreach and for "more opportunities for contact and for the expression of that strong latent feeling of appreciation and admiration which so evidently exists" (Davies, Clark et al. 2008:4). In a fascinatingly worded section, it states that "we are conscious that where adjustments in intangibles - consciousness, priorities and habits of mind and practice - are desirable, as we believe they are, there is never any mechanistic or immediate solution. The best that can be done is to set in train, across a broad front, a range of initiatives, none of which individually may be, or in fact should be, very dramatic, but which taken together will move matters forward in the right direction at the right time" (Davies, Clark et al. 2008:5). In other words, the report set out a number of related strategies aimed at enabling the surfacing, augmentation and movement of affects among members of the public. In the wording of this report, then, is a strategy of garnering public support based on the mediation and organisation of affective forms of life, chiefly through media and propaganda-based initiatives. Below, two examples of state initiatives that emerged in direct response to this report, and that draw on the affective power of the wounded body are discussed: the BBC screening of the Invictus Games in 2014 and the operations of the charity Help for Heroes. Both of these examples make visible, mediate and frame public encounters with wounded military bodies. As technologies of substantiation, they tie these bodies to ideas through juxtaposition and metonymy in the production of referential assemblages that draw on and channel affective responses to the wound. 
The Invictus Games was first staged in September 2014, and was heavily based on the USA's Warrior Games. It is a sports contest between physically disabled representatives of the "allied nations" injured during active military service. The event received extensive live and highlights coverage on BBC TV and radio, and was the subject of a primetime TV documentary. It frames visibilities of wounded military personnel, and, alongside other events where such bodies are presented to the public, such as remembrance parades and charity events, stages encounters between publics and military bodies. This staging augments affect through the excitement and suspense of competition, the spectacle of pageant and drill and the atmosphere of the crowd. It draws heavily on the affective atmospheres produced during the Olympic and Paralympic Games of London 2012, as well as of remembrance parades and military pageants ${ }^{\text {vii }}$. Its venue choice - the Copperbox Arena in the Queen Elizabeth Olympic Park - enabled the Invictus Games to reignite and rechannel the collective affects of the 2012 Paralympics and Olympics, as the BBC coverage of the event makes clear: "because we are here in Queen Elizabeth Park we are imbued with the spirit of London 2012 and that means an overwhelming feeling of optimism, which is particularly relevant to the Invictus Games, because these are about triumph, the triumph of hope over despair" (The One Show Special, Invictus Games 19:00 Wednesday 10 September 2014). Prosthetically-enhanced injured bodies are set in competition against a background of brass bands, military drills, a spectacular display by the Red Arrows (an aerobatic display team in the Royal Air Force) and a flyby by military helicopters as well as the more conventional semiotics of nationalism.

The primetime BBC screening of the Invictus Games personalised the encounter between publics and the wounded bodies of Games participants by drawing attention to the emotional responses of participants and spectators: "at one point I broke down in tears... it's so emotional being here now"... "When you think of the emotion that is going to be bubbling as the athletes enter into the arena this evening, what a moment for them"..."their hearts are going to be pumping". In commentary such as this, wounded bodies are rendered objects of connection, encouraging an engagement with such bodies as standing for a larger community of which the spectator is a 
member (see also Jervis, 2015). Throughout, coverage of the competition is intercut with biographical mini-documentaries that trace personal stories of injury, military service, rehabilitation and hope. These documentaries personalise the participants and enable further identification between the bodies of soldiers and those of publics. Individual biographies of participants gloss over the story of how injuries took place in order to focus on the processes of repatriation to British hospitals and the sophisticated rehabilitation and prosthetic technologies provided by public, private and voluntary organisations in a mixed economy of British technological superiority.

In these biographical mini-documentaries, battlefield footage and sporting footage are intercut, producing a relation of equivalency that reduces the damage of war to a means through which the body can be tested. Retellings of the process of wounding and rehabilitation tie each to a story of the body challenged but unbeaten, the losing of limbs just another means through which to demonstrate the (literally) steely resolve of the British military body. In such events, the technological advancement of western medicine is foregrounded, a marked difference from the prosthetics of amputees living within contemporary theatres of war (Fluri 2011). viii Military drill is combined with bodyshock as the camera dwells on those participants whose bodies are prosthetically modified, spectacularising their hybrid, machinic capacities. In this way, the Invictus Games, like the paralympic military programme and the Warrior Games in the USA, reveal the body of the wounded soldier/athlete as a powerful site for the production of narratives of service, sacrifice and technical supremacy, and of individual stories of overcoming adversity, willpower and recovery. While it could be argued that these stagings close off the wound rather than make it visible, the elaborate staging of wounded bodies in association with these material markers of militarism and nationalism takes as given the affective force of the wound; capitalising on it, personalising it and tying it into narratives that display the power of the state and the West (in whose name these people were maimed) but also its benevolent, technologically superior nature through the representation of elaborate forms of rehabilitation and prosthetic enhancement ${ }^{\mathrm{ix}}$. 
The Games, in their production of intensities of feeling and relays of association, draw publics into anencounter with wounded bodies as spectacle. The wound is a central node in this operation: it provides the event's telos and its force. Wounded bodies are showcased to publics through techniques of staging that trigger association, augment spectacle and intensify affect, in turn producing such bodies as liveable and grievable, enabling publics to feel that their pain matters (see Butler, 2004).

Powerful narratives of sacrifice underpinning these visibilities are accompanied by iconography that ties the intensities of the sports arena into wider cultures of militarism and nationalism. During the opening ceremony of the 2014 Invictus Games, participants from the British Armed Forces team hold up a flag emblazoned with the logo of the military charity Help for Heroes. Indeed, military charities are powerful political institutions through which wounded bodies are made visible. In the crowd, spectators wear sweatshirts and fleeces with the same logo. The prevalence of flags and logos of military charities produces relays of association that move into the spaces of everyday life. The wound is detached from the space of wounding (the battlefield) and incorporated into cultures of militarism, as publics are affectively drawn into a political community of support. The wounded body, through its association with the charity, bleeds outwards from specifically militarised spaces and dissipates through the bodies of the public.

Help for Heroes was set up in the UK after the Davies report, and was provided with heavy backing from the UK government. Its fundraising practices have to date become an enormously successful instrument in both generating income and support for military personnel, and for producing cultures of military support ${ }^{x}$. The charity's stated purpose is to provide top quality rehabilitation and support for wounded veterans; its website showcases state-of-the-art rehabilitation centres (www.helpforheroes.org.uk). A photographic book, The Hero Inside, published in support of the charity, tells the stories of various soldiers' rehabilitation, and pictures them engaged in sporting activity, with their families, and raising money for the charity (Shaw, 2009). These visibilities are part 
of a broader set of aesthetic strategies in relation to war wounding that emphasises recovery and western medical technology (Fluri, 2011). Through these techniques, the technofetishism of the wounded and reconstructed body becomes an object of wonder and admiration.

The charity sells merchandise including sweatshirts, T shirts and wristbands. The widespread wearing of this merchandise by members of the public during 2010-2015 normalised and personalised support for military personnel, encouraging forms of public participation that increase visibility of, and engagement with, the figure of the wounded soldier ${ }^{x i}$. The bodies of publics wear the imagined bodies of troops, further tying them into affective circuits that produce cultures of militarism and support. These material objects of merchandise call forth the spectral presence of the wounded body, and in doing so, allowing its force to inscribe itself on bodies again and again.

As well as offering a normalising function through the general increase of visibility of military signifiers, the ubiquity of these forms of militarisation, augmented through the power of the opened body, gave the intensities of political-affective experience such as the Invictus Games traction in everyday spaces. This occurred through participatory events, the ready availability of Help for Heroes merchandise and the charity's popularity at community events. Sweatshirts, sports tops, car stickers and wristbands provide opportunities for civilian publics to participate in cultures of militarism and express support for military personnel. Such ephemera make militarism and geopolitics tangible, and provide everyday hooks for the expression of geopolitical relations. Through their ubiquity, they provide recognisable signs that refer both to specific images of prosthesis-wearing heroic individuals and more generalised political-affective imaginaries of support and patriotism (see also Rech, 2012; Tannock et al., 2013; Tidy, 2015). The work of the charity in its public staging of wounding thus enables multiple political and subject positions to coalesce around the injured bodies of soldiers such that they are able to bring together a sense of support for individual military personnel without glorifying or celebrating war. Help for Heroes can be about 
"supporting the troops but not the war" (Dixon, 2012: 120), about individual narratives of injury and overcoming adversity, or of wounded personnel as victims of circumstance (Strachan, 2009).

The figure of the soldier is both a subject bearing witness to conflict and "a site through which a 'virtual' war becomes sensible and material" (Achter 2010:49): a site of substantiation. The modes of visibility discussed above work in and through the bodies of publics in the production of political worlds. Through their affective materiality, they substantiate ideas of nation, citizenship and sacrifice, and lend gravity and authority to such ideas ${ }^{\text {xii }}$. The augmentation of intensity and affective response that burgeon and prosper through sporting events and spectacles, and in everyday life, ties the wound into political communities and cultures that circumscribe ways of relating to the wounded and dead bodies of British military personnel. These techniques of visibility channel affective responses to wounding towards practices that contribute to cultures of militarism, and foreclose their translation into forms of political speech and practice that operate against such political discourses.

\section{Conclusion: substantiation, affect and the encounter}

As Scarry makes clear, the wounded body carries weight. And through these associative and affective relays, that weight is put to work in the conscription of publics. The examples above personalise wounding and death, figuring lives lost and damaged as lives worth grieving or lives victorious. The intensity felt at the moment of encounter with the wound becomes incorporated into a relay of associations that enable publics to feel part of a community, and moreover to participate in acts that build that community (Colman, 2009). These practices thus channel responses to the visibility of wounded military personnel towards that of support rather than political speech that calls into question their existence and practices. The potent untouchability of the pain and suffering of others makes certain responses, such as criticism of participation in war, or criticism of militarism, unavailable, while rendering responses of admiration and respect the only appropriate ones. Thus the forms of visibility that produce such wounded or heroic figurations 
render other forms of subject formation difficult. Wounding and death in the British Armed Forces is framed such that it incites collective affects of national identity, celebration, sentimentality and mourning.

More than a spectacle of sympathy, the Invictus Games provides a showcase for the wound, a site of substantiation, an arena for the propagation and augmentation of affects. It is a political-affective event that generates supportive publics. Both the Invictus Games and Help for Heroes draw on and produce conjunctures of ideas and imaginaries, including popular militarism, nationalism, Royalism, class, and austerity aesthetics. They involve encounters charged with sentiment and feeling, powered through bodies enacting and miming ideas of masculinity, tradition and nation. These affective technologies gain their force through the intensities produced by encounters with wounded, broken bodies. As these signs and affects move between spaces through reiterations of wound, they bleed together ideas and imaginaries, mutually reinforcing in the collective production of political-affective life. The cultures of militarism that these wounded bodies participate in are further augmented through everyday materials and practices. Though not ever-present, the wounded bodies that they showcase and make visible, through their power to substantiate ideas and their "heart-sickening reality", render unquestionable particular ways of relating both to the wound and to a more generalised political-affective disposition towards the nation and the armed forces.

. The wound can do powerful political work, as evidenced by these spectacles of war-ravaged bodies have been incorporated in a set of propagandist affective technologies in recent years. The power of wounding and death participates in the production of frames that conscript publics and elicit from them political-affective responses. Through its resonation with the affective dimensions of this process, Scarry's concept of substantiation has much to offer scholarship on the work that these technologies do. Wounded bodies are incorporated into regimes of public response, both affective and practical, that channel participation towards political outcomes in the ongoing statecraft of war. 
By looking deeper into the spaces, practices and institutions through which wounding is made visible, the process of substantiation becomes more evident, but also more politically nuanced.

Paying close attention to substantiation as a process, and the political logics of that process, makes visible the affective work being done in the framing and staging of the encounter. While certain forms of political-affective response are not inevitable, nor these techniques of power totalising, they do provide opportunities for particular engagements by bodies whose histories of subjectivation lead to their need or desire to participate in and encounter these collective affective spaces. They rely on bodies being historically situated in ways that open them up to being affected.

The politics of substantiation involves thinking about how broken or opened bodies are put to work in the conscription of popular consciousness and experience. To reread Scarry in the light of, and through, more recent work on affect and war, and on the representation of wounding, enables a much closer analysis of how the process of substantiation takes place, and the work that the wound does. In this way, the affective processes through which substantiation occurs, through the public display and mediation of wounded bodies, through which the word is made flesh and the flesh word, can be more clearly identified and opened up to critique.

References

Achter Paul. (2010) Unruly Bodies: The Rhetorical Domestication of Twenty-First-Century Veterans of War. Quarterly Journal of Speech 96: 46-68.

Anderson Ben. (2010) Morale and the affective geographies of the 'war on terror'. Cultural Geographies 17: 219-236.

Anderson Ben. (2011) Affect and biopower: towards a politics of life. Transactions of the Institute of British Geographers 37: 28-43. 
Anderson Ben. (2014) Encountering affect: capacities, apparatuses, conditions: Ashgate Publishing, Ltd.

Batts Callie and Andrews, David L. (2011) 'Tactical athletes': the United States Paralympic Military Program and the mobilization of the disabled soldier/athlete. Sport in Society 14: 553-568.

Blackman Lisa and Venn, Couze. (2010) Affect. Body \& Society 16: 7-28.

Butler Judith. (2009) Frames of war: when is life grievable?, London: Verso.

Butler Judith. (2004) Precarious life: the powers of mourning and violence, London: Verso.

Closs-Stephens, Angharad. (2014) The persistence of nationalism: from imagined communities to urban encounters, London: Routledge.

Clough Patricia Ticineto and Halley, Jean. (2007) The Affective Turn: theorising the social. Durham, NC: Duke University Press.

Colman Felicity J. (2009) Affective Imagery: Screen Militarism. Gilles Deleuze: Image and Text 8: 143159.

Cooper Nicola and Hurcombe, Martin. (2008) The body at war: wounds, wounding and the wounded. Journal of War \& Culture Studies 1: 119-121.

Coy Patrick G, Woehrle, Lynne M and Maney, Gregory M. (2008) Discursive legacies: The US peace movement and "support the troops". Social Problems 55: 161-189.

Davies Quentin, Clark, Bill and Sharp, Martin. (2008) Report of inquiry into national recognition of our armed forces.

Dawney, Leila. (2013a) The interruption: investigating subjectivation and affect. Environment and Planning D: Society and Space 31: 628-644.

Dawney, Leila. (2013b) The figure of authority: the affective biopolitics of the mother and the dying man. Journal of political power 6: 29-47.

Dawney, Leila (2018) Figurations of wounding: soldiers' bodies, authority and the militarisation of everyday life. Geopolitics DOI: 10.1080/14650045.2018.1490271. 
Dixon Paul. (2012) The British approach to counterinsurgency: from Malaya and Northern Ireland to Iraq and Afghanistan: Palgrave Macmillan.

Fluri Jennifer L. (2011) Bodies, bombs and barricades: geographies of conflict and civilian (in)security. Transactions of the Institute of British Geographers 36: 280-296.

Gavriely-Nuri Dalia and Balas, Tiki. (2010) 'Annihilating framing': How Israeli television framed wounded soldiers during the Second Lebanon War (2006). Journalism 11: 409-423.

Gregg Melissa and Seigworth, Gregory J. (2010) The Affect Theory Reader. North Carolina: Duke University Press.

Grondin, David. (2011) The other spaces of war: war beyond the battlefield in the war on terror. Geopolitics 16: 253-279.

Howe P. David. (2011) Cyborg and Supercrip: The Paralympics Technology and the (Dis)empowerment of Disabled Athletes. Sociology 45: 868-882.

Jervis John. (2015) Sympathetic Sentiments: affect, emotion and spectacle in the modern world, London: Bloomsbury.

Koven Seth. (1994) Remembering and Dismemberment: Crippled Children, Wounded Soldiers, and the Great War in Great Britain. The American Historical Review 99: 1167-1202.

Larsen Lotte. (1994) The yellow ribboning of America: A Gulf War phenomenon. Journal of American Culture 17: 11-22.

Managhan Tina. (2011) Grieving dead soldiers, disavowing loss: Cindy Sheehan and the im/possibility of the American antiwar movement. Geopolitics 16: 438-466.

Masco Joseph. (2013) The nuclear borderlands: The Manhattan project in post-cold war New Mexico: Princeton University Press.

Masco Joseph. (2014) The Theater of Operations: National Security Affect from the Cold War to the War on Terror: Duke University Press.

Massumi Brian. (2002) Parables for the Virtual: movement, affect, sensation, London: Duke University Press. 
McSorley Kevin. (2012) War and the body: militarisation, practice and experience: Routledge.

McSorley Kevin. (2014) Towards an embodied sociology of war. The Sociological Review 62: 107-128.

Millar Katharine M. (2015) 'They need our help': Non-governmental organizations and the subjectifying dynamics of the military as social cause. Media, War \& Conflict: 1750635215606867.

Rech Matthew Falko. (2012) A critical geopolitics of RAF recruitment.

Scarry Elaine. (1985) The Body in Pain: The making and unmaking of the world, Oxford and New York: Oxford University Press.

Shaw Gill. (2009) The Hero Inside, Shrewsbury: Quiller Publishing Ltd.

Silk Michael. (2013) The cultural politics of post-9/11 American sport: Power, pedagogy and the popular: Routledge.

Stahl Roger. (2009) Why we" support the troops": Rhetorical evolutions. Rhetoric \& Public Affairs 12: 533-570.

Strachan Hew. (2009) British Society and Armed Forces Day. RUSI. org 24.

Tannock Stuart, Burgess, Stephen and Moles, Kate. (2013) Military Recruitment, Work \& Culture in the South Wales Valleys: A Local Geography of Contemporary British Militarism. WISERD WORKING PAPER SERIES 9.

Taylor John. (1998) Body horror: photojournalism, catastrophe and war: Manchester University Press.

Tidy Joanna. (2015) Forces Sauces and Eggs for Soldiers: food, nostalgia, and the rehabilitation of the British military. Critical Military Studies: 1-13.

Woodward Rachel, Winter, Trish and Jenkings, K. Neil. (2009) Heroic anxieties: the figure of the British soldier in contemporary print media. Journal of War \& Culture Studies 2: 211-223. 


\footnotetext{
${ }^{i}$ More recently, there have been increasing numbers of war-injured refugees entering the UK. While there is no scope within this paper to discuss the specific politics of visibility involved with this group of bodies, it is worth noting this phenomenon and considering the different forms of political affect that they participate in in their encounters with publics.

ii in the light of changes in war over the past thirty years, we might instead think in terms of the performance of geopolitical ideas, rather than nation - see McSorley, this volume.

iii See Dawney, 2013b and Dawney, 2018 for further discussion of authority and the affective demand.

iv See Dawney, 2013b for an alternative discussion of the experiential authority of the veteran.

${ }^{v}$ While this paper focuses on how wounded bodies are mobilised for support for the military, wounding has also been used in anti-war discourse and imagery to invoke shock, disgust and revulsion (such as in the image of the burnt Iraqi soldier discussed by Jervis above, or in the artwork of George Grosz, and the work of Vietnam photographer Larry Burrows).

${ }^{v i}$ Discussion at "Re-engaging the Body in Pain" conference, University of Brighton, December 2015.

vii See Closs Stephens (2015) for further discussion of the affective atmospheres of London 2012.

viiiThis narrative has been criticised in disability studies with its invocations of the "Supercrip" (Howe, 2011)

and celebration of the "overcoming of adversity" story. The wounded veteran Simon Weston, himself a figure of "experiential authority" (Dawney, 2013b) has criticised the government for "hand selecting" wounded veterans for recruitment campaigns.

ix See Grabham (2009) and Fluri (2014) on the politics of the prosthesis-wearing soldier.

${ }^{x}$ Funded by central government, corporate and individual philanthropy and through fundraising events, the charity raised $£ 46.6 \mathrm{~m}$ in 2011, and $£ 32.6 \mathrm{~m}$ in 2012 (http://www.thirdsector.co.uk/voluntary-income-helpheroes-fell-nearly-fifth-last-financial-year/finance/article/1189799). See also Dawney, 2018.

xi In the United States, the discourse of "support the troops" has been powerful in mobilising publics behind recent wars through such objects and practices as yellow ribbons, war films and handshakes (Stahl, 2009;

Larsen, 1994; Coy et al., 2008). The role played by non-governmental organisations has been central in shaping a rhetorical shift towards the personal in the production of supportive publics and the processes through which consent is maintained and dissent is rendered problematic and non-patriotic (Managhan, 2011; Millar, 2015). xii To argue that these figures lend authority to particular beliefs and ideologies is in no way to suggest that the individual soldier's testimony has this gravity and this power - despite being witness to death and violence, the figure of the soldier is rarely a speaking subject and his or her testimony is on the whole closed off and silenced.
}

\section{Biography}

Leila Dawney is a cultural geographer and theorist of power, affect and embodiment. Her research concerns forms of experience and subjectivity produced in and through spaces of late capitalism. She is a Lecturer in Human Geography at the University of Exeter and a member of the Authority Research Network. 